\title{
THE INFLUENCE OF THE OUT-OF-FAMILY CARE INSTITUTIONS ONTO CHILD'S DEVELOPMENT
}

\author{
LUBOVA VASECHKO \\ Lv06028@lanet.lv \\ University of Latvia, Latvia
}

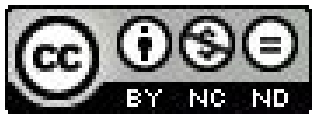

\begin{abstract}
The article offers the analysis of the out-of-family care institutions and their influence on child's development. Despite the fact that the institutional out-of-family care provides the subject with physical security and satisfies his basic needs it cannot provide the most important aspect of the development of the child - the close relationship with at least of one of the adults who would be able to captivate and become a legal guardian for several years.

Key words: institutional out-of-family care, care, deprivation, child development
\end{abstract}

Both the parents and the surrounding environment play an important role in the development of every child's personality. In order to develop in a healthy way, every child needs to be loved by their parents. It is necessary for the child to receive the parents' warmth, intimacy, and care. The parents are the ones who develop the intellectual and motoric functions of their child as well as their personality (Āre, 2003). However, there are cases when living in the biological family is harmful for the child. In such cases, the duty of family court is to ensure out-of-family care for the subject. In the Republic of Latvia, out-of-family care is provided by legal guardians, foster families and child care institutions (Bèrnu tiesību aizsardzibas likums, 1998).

Institutional out-of-family child care is currently a heavily discussed topic in Latvia. This is the phenomenon when the devastating influence of the out-of-family care institutions is finally taken into consideration. New ideas about alternative care possibilities pop up. The Committee on the Rights of the Child of the United Nations gave the folllowing recommendations to the Latvian authorities already six years ago: "To provide that assigning the child to the out-of-family care institution would be the last possibility to solve his family's problems and can be used only if the care is considered to be acceptable for the specific child" (Bèrnu tiesibu komitejas 2006. gada 28. jünija noslēguma apsvērumi: Latvija, 33.punkts, 2006, article 33).

Researchers throughout the world have proved that if one wants a child's development to be successful, the child must be raised in a family environment where both the care according to his needs and the trusted person are available.

Despite the trend that more and more children are placed into the legal guardian or foster families the statistical data analysis proves that the amount of children under institutional out-of-family care remains stable. Nowadays $22 \%$ of all the children - the subject of the out-of-family care are under the institutional 
care (Bārintiesu iesniegto ikgada valsts statistikas pārskatu par bārintiesu darbu 2010. gadā analizze, 2011).

According to UN guidelines regarding alternative child care in countries where numerous child care institutions remain operating, it is demanded that alternative ways of taking care of children are developed, and strategies of reducing the amount of care institutions are implemented, until they are completely eradicated (Guidelines for the alternative care of children, 2009).

It is impossible to claim that institutional care system should be eliminated totally, since there are still numerous cases when this kind of care best fits the specific needs of kids and teenagers. However, it is necessary to change the system in such a way that as many children as possible benefit from family rather than institutional care. Children under family care receive love, warmth and real care from adults. It is proven that the experience of one's childhood is the important baseline for their further life. If the experience is positive, there is greater probability that the childwill be capable of finding the right place in the society and creating their own family successfully as an adult.

While under institutional care the subject undoubtedly receives all the necessary physical care with the basic physical needs highly satisfied, the child still lacks complete psychological development (Âre, 2003).

\section{CHARACTERISTICS OF INSTITUTIONAL CARE ENVIRONMENT}

While analyzing the institutional care environment, it is impossible not to mention what out-of-family institutional care is unable to provide and what thus obstructs the child's many-sided development. These aspects are: the shortage of parents' love and care, the non-personified and non-motivating environment; the lack of opportunity for the child to be alone, the fear of other people's reactions; the child often being afraid to say or do something they are not sure about in order to avoid any negative reaction from their surrounding; the child experiencing a constant need of emotional contact that the environment is unable to satisfy; the child being dissatisfied because of the lack of heart-to-heart talk; the child not being able to develop a sense of belonging to the family as well as failing to understand its role; child is limited by other children in his actions, - this affects development of the child limiting other children by his action which is another reason of the delayed development of the child; having a disturbed self-identity; having inadequate experience and knowledge about adults life etc. (Ozola, 2011; Āre, 2003).

Out-of-family institutional care limits the development of the child, the subject is not motivated to fully use their abilities and, as a consequence, deprivation occurs.

Both $20^{\text {th }}$-century and the most recent research (Bowlby, Langmeier, Mateichiks, Batnia, Tolstih, Prihozhan etc.) highlight deprivation, understood asa loss or limitation of the abilities to fulfilone's needs, essential for survival (Batna or Batnia, 2007).

V Batnia emphasizes that "one of the most significant problems of the institutional child care is the deprivation that the children experience before getting into the institutional care and living there" (Batna or Batnia, 2007). 
A. Prihozhan and N. Tolstih distinguish 2 types of deprivation: one is the situation when since their birth the human has limited stimulation from the environment (impulses, irritants) and certain significant needs don't even originate; the other type of deprivation may occur when the need already exists but its fulfillment has become impossible. The first case is sometimes called "privation" meaning "separation" or "detraction" Prihozhan, Tolstih, 2005).

As scientists J. Langmeier and Z. Mateichick define (Laugmeier, Matejcek, 1984) the deprivation is the psychological state that occurs as the result of one's living conditions when the subject is unable to satisfy his basic psychological needs at sufficient level and in sufficient space of time. The authors consider that while researching deprivation it is significant to define the psychological needs for every age of the child as well as to define the needs which influence is the most devastating in the case they are unsatisfied (Laugmeier, Matejcek, 1984). This article considers the simulating environment, the need of social connections (especially with the mother or her replacement), the need of self-fulfillment as the very essential need of every child.

A lot of recognition goes to the British psychiatrist J.Bowlby for his remarkable discoveries in the field of deprivation. J. Bowlby notices the multiple aspects of deprivation, whose influence is found in institutional child care facilities. For example, the child experiences a lack of stimulation, and is not given a healthy environment for his development that under usual conditions happens "as impact" because the environment is not structured properly. The frustration has a negative influence as well, which is connected with the child's need to feel their mother's care and love. If these needs are fulfilled, J.Bowlby considers that the other types of frustration cannot be of such great significance for the child's further development (Bowlby, 2003). What this statement points out is the primary condition of the child's psychological health and development that depends on love, care and support from the adults. That proves once again that under institutional care, even in the best possible conditions, the subject is unable to develop properly since he or she lacks this primary condition.

\section{THE INFLUENCE OF INSTITUTIONAL CARE}

Institutional care leaves a negative influence on the child's emotional development. This happens because institutional care environment doesn't provide constant deep emotional intimacy with at least one adult. The interaction of different feelings with an adult who is capable of creating a deep and concrete connection thus ensuring a basis for the emotional self-identity is essential for a sufficient psychological development. The children living in the social isolation for a long-term receive serious distractions of their capabilities and psychological health (Āre, 2003).

J. Bowlby claims that if an infant or a child is surrounded by their mother's or father's love, he or she is growing without the pressure from their own libido and without an excessive tendency for hate. But if the child is deprived of love and care, there is a possibility that his or her libido desire grows so intensively that the 
subject is in a constant search of love, care and intimacy while hating the ones who in his or her opinion are unable to provide what they search for. Additionally, if the relationship with the parent or the parent's substitute was broken for some time, the subject suffers intensively while getting his future relationships with the person worse at least for the period until he can trust the person again (Bowlby, 2006).J.Bowlby highlights the impossibility of getting a close emotional relationship with an adult as well as breaking an existing connection as the factors most devastating for the child's psychological well-being Bowlby, 2006).

D. Tenne, having researched the child's self-identity and its formation in the process of the child's personality development, came to the conclusion that the child's need of being emotionally close to someone and of satisfying their needs in general is a positive long-lasting experience as well as the condition ensuring a harmonic psychological development of the subject. She points out that the child's experience of relationships is determined by dominating self-identification aspects. The child's positive self-identification relies on empathy and the development of their language skills. If the child's need of intimacy remains unsatisfied, it results in disconnection from society and in a lack of trust in it, as well as in constant depressive feelings, which leads to different somatic and psychiatric symptoms. As a result of the lack of emotional contact, the child's negative feelings, emotional poorness, lack of emotions and inability to address the needs of others can expose (Tenne, 1998). These arguments especially highlight the huge responsibility that the court of wards takes when deciding whether to put a child into out-of-family institutional care placement or into another family, and how thoughtfully in needs to be evaluated by the authorities.

Characterizing the child who grows under institutional care, J. Bowlby points out the most recognized works of J. A. Ambrose (1961), S. Provence, R. Lipton (1962), and M. Ainsworth (1962). He indicates that the children who are raised in the family give their first smile several weeks earlier than the ones who had been placed under the institutional out-of-family care. The smile appears accordingly in the 6th-10th week of the child's life or in the 9th-14th week of the child's life. The infants who lack family care produce much fewer sounds than their peers. The difference between the children who grow in their families and the children who grow under institutional care becomes more and more noticeable with age. The ones under institutional care are much less motivated to communicate, their emotions are poorer and at the age of one they don't show any relationship to adults. The lack of such relationship is especially noticeable when the children are limited in achieving their desires: even then they quite rarely ask adults for help. J. Bowlby points out the influence of the mother on the development of the child, indicating that the mother is the main source of information for her baby. Apart from the stimulation that the mother delivers to her child while communicating with them, she also provides the possibility to explore the surrounding environment more actively, which is meaningful for sensory development. J. Piage also agrees with this (Bowlby, 2003, Piage, 2008).

It is a phenomenon that children usually maintain a strong bond with the mother even if they were tyrannized by her. It is hard to understand and accept the 
fact that the child is capable of experiencing deep feelings for parents with deviant behavior. When handed over to institutional care and deprived of the relationship with their parents, the child becomes super-sensitive and vulnerable. Even if during discussing their emotions the child is calm and peaceful, they still require the help of a person they trust. J. Bowlby thinks it is extremely important to provide the child with a single and constant person replacing the mother. One that the child would be able to get used to quite soon. Only in this case is the child able to get over the loss successfully and reorganize their internal world. The mother replacing the person's real mother should react and be available whenever needed as well as intervene always when the child is facing difficulties. J. Bowlby claims that it depends on the replacing person's reactions whether the child will be mentally healthy or not (Bowlby, 2003).

J. Langmeier and Z. Mateichick while describing the child's psychological portrait point out that children of school age who are subjects of out-of-family institutional care are different from their peers in not being quite prepared for education. They usually have lower grades, they have a difficult experience while learning to read. An emotional disfunction that appears as regressive symptoms and a desire to hold other people's attention can always be noticed too (Laugmeier, Matejcek 1984).

V. Batnia and I. Furmanov highlight the outbreaks of aggression that are typical for children raised in institutional care. The children have an excessiveneed for contact with adults andlack emotional relationships and intimacy. The educational personnel often changes the facilities, the children are often transferred form one group to another, or even switched among different institutions. At the same time they demonstrate an excessive need for the company of adults, which, if remains unsatisfied, changes into aggressiveness in the relationships they desire so much (Batnia, 2007; Furmanov, 2007).

Aggression combined with the inability to take the initiative creates a parasitic attitude, a tendency to wait and demand a solution of the subject's problems. These particular qualities disturb the child's self-identification and the set-up of self-worthiness, self-esteem and the ability to evaluate other people around them who are of great help when emotional relationships are created (Batia, 2007; Furmanov, 2007).

A. Prihozhan discovers the poorness of the child's motivational aspects that is interconnected not only with the limits of his life experience but also with the type of the relationships he is having with the adults. She points out that children who are raised under institutional care have a hypertrophied need for contact with adults. If the children are in constant contact only with their peers, they do not successfully develop qualities necessary for resolving conflicts. As a result, aggressiveness is often noticed, as well as a tendency to blame others and the inability to admit one's own guilt (Prihozhan, Tolstih, 2005).

Research that has been made in 32 countries (within the Bucharest Early Intervention Project) has pointed out the risk of institutional care for children. Environment unsuitable for the child harms their further development, hinders their cognitive development (the latency in development) and causes atrophy of the brain. A meta-analysis (the use of statistical methods to generalize results obta- 
ined from different research studies) of 75 studies where data on more than 38000 children from 19 countries has been collected shows that the IQ level of children who have grown under out-of-family institutional care is approximately 20 degrees lower than the IQ level of children who have been provided with family care (Williamson, Greenberg, 2010).

D. Johnson (Johnson, n.d.), pediatrician and $\mathrm{PhD}$ in philosophy, in his study on institutional care points out that a child who was subject to institutional out-of-family care and was then placed under family care requires 2-5 years for their development to go back to normal after the harm caused by institutional care placement.

D. Johnson adds that nevertheless not all problems can be solved, even in this period of time. Some of them remain to be long-term ones and nobody is able to predict when some new deviations can be discovered. There are children who even after many years spent in the family are not capable of catching up with their peers in their own emotional development. The child requires very special assistance as soon as their time under institutional care is over, even if their behavior deviations remain invisible, which is especially likely when the subject is under the age of 2.

J. Williamson and A. Greenberg in their thesis Families, not orphanages (Williamson, Greenberg, 2010) have popularized the opinion that some families might not be perfect for the child's development, but they still remain a much better choice than out-of-family institutional care placement. They point out that the child needs much more than a well-organized physical environment. What is most important is satisfying the need of love, intimacy and care as well as the need of being safe (Williamson, Greenberg, 2010).

Researches conducted over the last 50 years still repeat the same theses: long-term placement under out-of-family care in one's childhood leads to recurring problems in communication and relationships, deviations in mental development, difficulties in acting as parent, etc. (Ford, Kroll, 1995).

A lot of evidence exists for the fact that out-of-family institutional care provokes problems in the development of children. The most important disadvantage of this solution is the child's inability to create long-term relationships with adults in their environment. The changes of the personnel and the big numbers of children in one group are the main reasons for that. Institutional care placements usually have their own "culture" that differs from the one accepted in family. This "culture" is usually strict and limits the opportunities of the individuals to socialize. It leaves a very negative impact on the subject's ability to maintain relationships for the whole life. Institutional care not only harms the child's potential but also limits their economic, political and social future. It creates major difficulties for the subject's integration into the surrounding society. Statistical data gathered in Russia shows that one in three children raised in out-of-family care becomes homeless after institutional care is over, one in five commits some crime and one in ten commits suicide (J. Williamson, A. Greenberg, 2010). Such comprehensive researches are not available in Latviam, but it is justified to assume that Latvia has similar problems with youth raised under institutional care. 
Childhood is the main period of development of the human being. The experience gained in pre-school age influences the subject's later life as well. For the child to succeed in all the three aspects of development (cognitive, social, mental), an appropriate environment is needed, which stimulates the child and where more attention is paid to their needs. Institutional care is not favourable for the child's development. This type of care results in deviations in one's mental health and leaves a negative impacts on the development of the personality.

\section{REFERENCES}

Āre, I. (2003). Manas mājas - bērnunams [Orphanage is my home]. Pirmsskolas izglìtība, 1, 24 - 26.

Batņa, V. (2007). Rosinot bèrna iekšèjo pasauli [Encouraging the child's inner world]. Rīga: RaKa.

Bārintiesu iesniegto ikgada valsts statistikas pārskatu par bārintiesu darbu 2010.gadā analīze [The analysis of the statistical performance data submitted on the annual basis by court of wards] (2011). Rìga: Labklājības ministrija.

Bērnu tiesibu aizsardzibas likums [Children Rights Protection law] (1998). Rīga: Latvijas Saeima. Retrieved from http:/ / www.likumi.lv/ doc.php?id=49096

Bērnu tiesibu komitejas 2006. gada 28. jünija noslēguma apsvērumi: Latvija, 33.punkts [Children Rights Committee's considerations for Latvia] (2006). Apvienoto Nāciju Organizācija.

Bowlby, J. (2003). Привязанность [The attachment]. Moscow: Gardariki

Bowlby, J. (2006). Создание и разрушение эмоциональных связей [The creation and destruction of emotional ties]. Moscow: Akademicheskiu proect.

Ford, M., Kroll, J. (1995). There is a better way: Family - based alternatives to institutional care. North American Council on Adoptable Children, Research Brief, 3, 18-42.

Furmanov, I. А. [Фурманов, И. А.] (2007). Агрессия и насилие: диагностика, профилактика [Aggression and violence behavior: the diagnosis and prevention]. Saint Petersburg: Rech.

Guidelines for the alternative care of children (2009). Apvienoto Nāciju organizācijas Ģenerālās asamblejas rezolūcija.

Johnson, D. (n.d.). Adopting an institutionalized child: what are the risks?. Retrieved February 11, 2012 from http://www.adoption-research.org/risks.html

Laugmeier J., Matejcek, Z. (1984). Психическая депривация В детском Возрасте [Psychology deprivation in childhood]. Prague: Avisenum.

Ozola, V. (2001). Sociālā vide un bērnu nama bērni [Social environment and children from an orphanage]. Skolotäjs, 3, 105-107.

Piaget, J. (2008). Речь и развитие ребёнка [Speech and child development]. Moscow: Rimis.

Prihozhan, A. M., Tolstih, N. N. [Прихожан, А. М., Толстых, Н. Н.] (2005). Психология сиротства [The psychological difficulties of orphans]. Saint Petersburg: Piter.

Tenne, D. (1998). Pirmsskolas vecuma bērnu pašizjūtas specifika bērnunamā: promocijas darbs [Preschool children's nature of sense of self in the orphanage: the thesis]. LU Pedagoǵijas un psihologijas institūts. Rīga: Latvijas Universitāte.

Williamson, J., Greenberg, A. (2010). Families, not orphanages. Batter Care Network. 